\title{
Drug Sample
}

National Cancer Institute

\section{Source}

National Cancer Institute. Drug Sample. NCI Thesaurus. Code C96974.

A unit of a pharmaceutical product intended to promote the use of the drug and not intended for sale. 